\title{
Update on the clinical utility and practical use of ropivacaine in Chinese patients
}

This article was published in the following Dove Press journal:

Drug Design, Development and Therapy

9 September 2014

Number of times this article has been viewed

Man Li

Li Wan

Wei Mei

Yuke Tian

Department of Anesthesiology, Tongii Hospital, Tongji Medical College, Huazhong University of Science and Technology, Wuhan, People's Republic of China

\section{Video abstract}

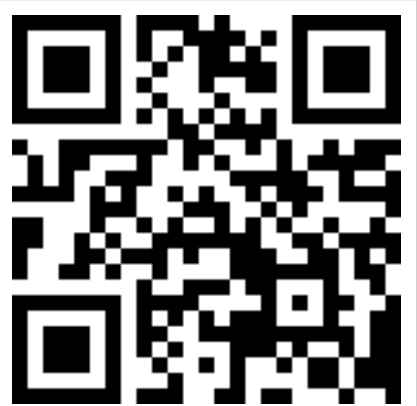

Point your SmartPhone at the code above. If you have a $Q R$ code reader the video abstract will appear. Or use: http://dvpr.es/WMp28T

Correspondence: Wei Mei

Department of Anesthesiology,

Tongji Hospital, Tongji Medical

College, Huazhong University of

Science and Technology, Jiefang

Ave 1095, Wuhan 430030, People's Republic

of China

Tel +86278366 3173

Fax +86 2783734643

Email wmei@tjh.tjmu.edu.cn

Yuke Tian

Department of Anesthesiology,

Tongji Hospital, Tongji Medical College,

Huazhong University of Science and

Technology, Jiefang

Ave 1095, Wuhan 430030, People's Republic

of China

Tel +862783662853

Fax +862783734643

Email yktian@tjh.tjmu.edu.cn
Abstract: We reviewed the Chinese and English literature for efficacy and tolerability data as well as pharmacological properties of ropivacaine in Chinese patients. Ropivacaine is a longacting amide local anesthetic agent that elicits nerve block via reversible inhibition of sodium ion influx in nerve fibers. The available evidence in the literature on anesthesia practice indicates that ropivacaine produces equally surgical sensory block and postoperative and obstetrics analgesia with good maternal and fetal outcome to those of bupivacaine or levobupivacaine. It appears to be associated with comparable onset, quality, and duration of sensory block, but with a lower incidence or grade of motor block, compared to bupivacaine. The satisfaction of both patients and surgeons is high when ropivacaine is used. Thus, ropivacaine appears to be an important option for regional anesthesia and for the management of postoperative and labor pain, with its enhanced sensorimotor differentiation blockage at lower concentrations and enhanced safety at higher concentrations.

Keywords: local anesthetics, anesthesia, analgesia, pharmacology, efficacy, side effect

\section{Introduction}

Ropivacaine is the pure $\mathrm{S}(-)$-enantiomer of propivacaine, synthesized in 1957 and then released into clinical practice in 1996 in the US and subsequently introduced into the People's Republic of China in 1999. This new molecule was developed for the purpose of achieving a lower risk of cardiovascular toxicity and improving the relative sensory and motor block profiles compared to previous local anesthetics. ${ }^{1}$ Ropivacaine has been reported to have been safely used in peripheral nerve blockade via different routes. ${ }^{1}$ Since Wong et al reported the efficacy and safety of ropivacaine in Chinese patients undergoing caesarean section in 2003, use of ropivacaine for spinal anesthesia in obstetric and non-obstetric patients has been increasing nationwide. ${ }^{2}$ According to the China Hospital Pharmaceutical Audit, ropivacaine, among several available longacting agents (bupivacaine and levobupivacaine), is the most commonly prescribed local anesthetic for regional anesthesia and pain management in the People's Republic of China. ${ }^{3}$ This review focuses on the efficacy and tolerability of ropivacaine when used in regional anesthesia and pain management and provides an overview of its pharmacological properties in Chinese patients.

\section{Pharmacodynamic properties}

Like other local anesthetics, ropivacaine causes reversible inhibition of sodium ion influx in nerve fibers, thus preventing depolarization of cell membrane and subsequently impairing impulse propagation. ${ }^{4,5}$ This action is potentiated by dose-dependent 
inhibition of potassium channels. ${ }^{6}$ Ropivacaine is less lipophilic than bupivacaine and is less likely to penetrate large myelinated motor fibers. Therefore, it is more selective for pain transmitting nerves than motor function fibers. ${ }^{7,8}$

Clinical studies in various patient populations suggest that ropivacaine is less potent than bupivacaine and levobupivacaine. These studies ${ }^{9-13}$ evaluated the minimum local analgesia concentration (MLAC) or the median effective dose (ED50) of ropivacaine and the comparator agents and found that MLAC and ED50 values were higher for ropivacaine than bupivacaine or even levobupivacaine. An obstetric study comparing the MLAC of ropivacaine with levobupivacaine in women in labor showed that the MLAC for ropivacaine $(0.092 \%, 95 \%$ confidence interval [CI]: $0.082 \%-0.102 \%)$ was higher than levobupivacaine $(0.077 \%$, 95\% CI: $0.058 \%-0.096 \%$ ), indicating that levobupivacaine may be $19 \%$ more potent than ropivacaine. ${ }^{9}$ A recent study that was designed to evaluate the analgesic potency ratios for intrathecal ropivacaine, levobupivacaine, and bupivacaine found that the intrathecal minimum local analgesia dose was 3.64 (95\% CI: 3.33-3.96) mg for ropivacaine, 2.94 (95\% CI: 2.73-3.16) mg for levobupivacaine, and 2.37 (95\% CI: 2.17-2.58) mg for bupivacaine, which suggested a potency hierarchy of spinal bupivacaine $>$ levobupivacaine $>$ ropivacaine. ${ }^{10}$ Other clinical trials enrolling Chinese patients also demonstrated the lower potency of ropivacaine. ${ }^{11,78}$ One study investigating the ED50 of intrathecal ropivacaine, levobupivacaine, and bupivacaine for lower limb surgery in Chinese patients found that the ED50 were 8.41 (95\% CI: 7.15-9.67) $\mathrm{mg}$ for ropivacaine, 5.68 (95\% CI: 4.92-6.44 mg) for levobupivacaine, and 5.5 (95\% CI: 4.90-6.10) $\mathrm{mg}$ for bupivacaine. The relative anesthetic potency ratios are 0.97 (95\% CI: 0.81-1.17) for levobupivacaine/bupivacaine, 0.65 (95\% CI: 0.54-0.80) for ropivacaine/bupivacaine, and
0.68 (95\% CI: 0.55-0.84) for ropivacaine/levobupivacaine. ${ }^{11}$ Although ropivacaine has lower potency than bupivacaine or levobupivacaine at lower doses (MLAC or ED50), it has similar efficacy to these two agents at clinically relevant doses and concentrations in surgical anesthesia. ${ }^{12,13}$

\section{Pharmacokinetic properties}

The route of administration of ropivacaine as well as tissue vascularity at the site of administration determines the absorption. After epidural administration of ropivacaine $1.5 \mathrm{mg} / \mathrm{kg}$, the mean plasma maximum concentration $\left(\mathrm{C}_{\max }\right)$ was $1.31 \mu \mathrm{g} / \mathrm{mL}$, and the mean time to $\mathrm{C}_{\max }$ was 11.8 minutes. ${ }^{14}$ Using $0.1 \%-0.5 \%$ solutions of ropivacaine, the ED50 to initiate epidural analgesia in early labor was 18.4 (95\% CI: 13.4-25.4) mg. ${ }^{15}$ Several studies were designed to evaluate the pharmacokinetics of ropivacaine in Chinese patients, and the plasma ropivacaine absorption data in Chinese patients are summarized in Table $1 .{ }^{14,16-18}$ Amide local anesthetics always display a biphasic absorption pattern, with rapid absorption of a small quantity of drug by highly perfused tissues/organs, followed by a slower absorption of the remainder of the drug into less perfused tissues/organs. The early absorption speed of ropivacaine can be affected by ropivacaine-induced vasoconstriction. However, a study examining the effects of various ropivacaine concentrations $(0.25 \%, 0.5 \%$, and $0.75 \%)$ on pharmacokinetic profiles following transversus abdominal plane did not find any difference among the concentrations. ${ }^{19}$ The mean half-time of the rapid absorption is approximately 14 minutes, while the mean absorption half-time of the slower phase is approximately 4.2 hours. ${ }^{20}$ Epidural ropivacaine pharmacokinetics were found to be affected by age, ${ }^{21}$ as the fraction absorbed was decreased and the elimination half-time was longer in older compared with younger patients. Based on these

Table I Summary of absorption pharmacokinetics of ropivacaine in Chinese patients

\begin{tabular}{|c|c|c|c|c|c|c|c|}
\hline & $\begin{array}{l}\text { Route of } \\
\text { administration } \\
\text { (number of } \\
\text { patients) }\end{array}$ & $\begin{array}{l}\text { Concentration } \\
\text { of ropivacaine } \\
\text { used }\end{array}$ & $\begin{array}{l}\text { Total } \\
\text { doses of } \\
\text { ropivacaine }\end{array}$ & $\begin{array}{l}C_{\max }, \text { arterial } \\
(\mu \mathrm{g} / \mathrm{mL})\end{array}$ & $\begin{array}{l}C_{\max } \text {, venous } \\
(\mu \mathrm{g} / \mathrm{mL})\end{array}$ & $\begin{array}{l}t_{\max }, \text { arterial } \\
(\mathrm{min})\end{array}$ & $\begin{array}{l}t_{\max }, \text { venous } \\
(\mathrm{min})\end{array}$ \\
\hline \multicolumn{8}{|l|}{ Adult studies } \\
\hline Lee et $\mathrm{al}^{1 / 4}$ & Epidural block (24) & NA & $1.5 \mathrm{mg} / \mathrm{kg}$ & I.3I (0.39) & I.3। (0.5) & $8.8(5.3-14.6)$ & II.8 (6.6-2I.I) \\
\hline Karmakar et al ${ }^{16}$ & $\begin{array}{l}\text { Thoracic paravertebral } \\
\text { block (20) }\end{array}$ & $10 \mathrm{mg} / \mathrm{mL}$ & $2 \mathrm{mg} / \mathrm{kg}$ & $2.47(0.5)$ & NA & $7.5(2.5-25)$ & NA \\
\hline Chen et $\mathrm{al}^{17}$ & $\begin{array}{l}\text { Intra-articular } \\
\text { administration (18) }\end{array}$ & $7.5 \mathrm{mg} / \mathrm{mL}$ & $150 \mathrm{mg}$ & NA & $0.91(0.4)$ & NA & $55.8(33.6)$ \\
\hline \multicolumn{8}{|l|}{ Child study } \\
\hline Karmakar et al ${ }^{18}$ & Caudal block (20) & $2 \mathrm{mg} / \mathrm{mL}$ & $2 \mathrm{mg} / \mathrm{kg}$ & NA & $0.67(0.16)$ & NA & $61.9(20.6)$ \\
\hline
\end{tabular}

Note: Values are mean (SD), or mean ( $95 \%$ confidence interval) if SD could not be found in the paper.

Abbreviations: $C_{\max }$, maximum concentration; $N A$, related data not available; $S D$, standard deviation; $t_{\max }$, time to $C_{\max }$. 
clinical findings, it is recommended that elderly patients receive reduced doses of ropivacaine, according to their physical status.

Alpha-1-acid glycoprotein (AAG) is the main binding site for ropivacaine $\mathrm{e}^{7,12}$ and binds basic drugs in a low-capacity, high-affinity fashion. The unbound drug concentration is considered to be related to systemic toxicity. Plasma levels of AAG are increased by trauma, surgery, and other pathophysiological states, which in turn can alter total and unbound plasma concentration of ropivacaine. ${ }^{22}$

Ropivacaine is predominantly eliminated by extensive metabolism in liver, which depends on hepatic blood flow as well as the degree of protein binding. ${ }^{23}$ Two cytochrome $\mathrm{P} 450$ (CYP) isoenzymes, CYP1A2 and CYP3A4, are responsible for the formation of $3^{\prime}$-hydroxy-ropivacaine and $2^{\prime}, 6^{\prime}$-pipecoloxylidide, respectively, with typical hepatic extraction ratios between 0.3 and $0.7 .{ }^{24,25}$ After administration of a single intravenous dose of radiolabeled ropivacaine, $86 \%$ of the dose was excreted in the urine after 96 hours, mainly as 3 -hydroxy-ropivacaine (37\% of the dose), with only $1 \%$ of the dose being excreted unchanged. ${ }^{26}$ Most of the radioactivity (about 68\%) was excreted within 12 hours.

\section{Therapeutic efficacy}

Ropivacaine has increasingly been used in clinical anesthesia practice and pain management over the last few years in the People's Republic of China. Numerous clinical trials ${ }^{27-31,52-58}$ have evaluated the efficacy of ropivacaine by comparing primarily with bupivacaine or levobupivacaine, and the efficacy in providing a profound sensory block suitable for surgical anesthesia and postoperative and labor analgesia when administrated by various routes has been established.

\section{Epidural administration}

Epidural ropivacaine provided effective anesthesia for Chinese patients undergoing elective cesarean section, ${ }^{27}$ abdominal surgery, ${ }^{14}$ breast cancer surgery, ${ }^{28}$ and hip ${ }^{29}$ or lower limb surgery, ${ }^{30}$ as well as effective analgesia following different surgeries. ${ }^{31}$ Ropivacaine $0.5 \%$ or $0.75 \%$ epidurally has been demonstrated to provide a clinically similar onset of sensory and motor block to that of bupivacaine $0.5 \%$. $^{32,33}$ When $0.5 \%$ ropivacaine was administered, the median duration of analgesia for surgery (spinal nerves T6-S3) was 1.7-4.2 hours, whereas the median duration of complete motor block was 0.9 hours. $^{32}$ Compared with $0.5 \%$ bupivacaine, $0.75 \%$ ropivacaine resulted in greater decrease of maternal heart rate; however, it did not influence neonatal well-being, which was evaluated by Apgar scores 1, 5, and
10 minutes after delivery and by umbilical arterial blood-gas analysis. ${ }^{34}$ Patients showed slightly higher satisfaction with ropivacaine anesthesia compared with bupivacaine anesthesia (93\% versus 87\%), although there was no significant difference. ${ }^{32}$ By conducting a meta-analysis, Hillyard et al found that, for emergency cesarean section anesthesia, neither epidural ropivacaine nor bupivacaine is the first choice. If the speed of onset is important, a lidocaine and epinephrine solution appears optimal; if the quality of anesthesia is paramount, $0.75 \%$ ropivacaine is suggested. ${ }^{35}$

Pouzeratte et $\mathrm{al}^{36}$ reported that patient-controlled epidural analgesia with $0.125 \%$ bupivacaine was more effective than a mixture of $0.125 \%$ ropivacaine and $0.5 \mu \mathrm{g} / \mathrm{mL}$ sufentanil in patients after abdominal surgery, and that $0.2 \%$ ropivacaine alone was less effective than the mixture. However, a recent study showed that patient-controlled epidural infusion of $0.2 \%$ ropivacaine, $0.125 \%$ bupivacaine, or $0.125 \%$ levobupivacaine produced similar pain relief and postoperative sensorimotor differentiation in patients undergoing lower limb surgery. ${ }^{37}$

\section{Intrathecal administration}

Bupivacaine was formerly considered as the first choice for spinal anesthesia in most hospital in the People's Republic of China. Since very small doses of local anesthetic are required in spinal anesthesia, the risk for bupivacaine-related systemic toxicity has not been an issue. ${ }^{38}$ Nevertheless, ropivacaine has been administered intrathecally for regional anesthesia for obstetric patients and non-obstetric patients in recent years.

The efficacy of intrathecal ropivacaine for regional anesthesia is mainly concluded from studies of Chinese patients undergoing cesarean section, ${ }^{39,40}$ urological surgery, ${ }^{41}$ or orthopedics surgery. ${ }^{11,42}$ Doses of ropivacaine used for spinal anesthesia have ranged from 8 to $22.5 \mathrm{mg}$, and it has been suggested that ropivacaine is less potent than bupivacaine. ${ }^{43-45}$ A comparative study enrolling parturients undergoing elective cesarean showed that intrathecal ED50 for motor block was 5.79 (95\% CI: 4.62-6.96) $\mathrm{mg}$ for ropivacaine, 4.83 (95\% CI: 4.35-5.32) mg for levobupivacaine, and 3.44 (95\% CI: $2.55-4.34) \mathrm{mg}$ for bupivacaine. ${ }^{46}$ However, McNamee et al reported that $17.5 \mathrm{mg}$ plain ropivacaine $0.5 \%$ provided similarly effective spinal anesthesia as $17.5 \mathrm{mg}$ plain bupivacaine $0.5 \%$ for total hip arthroplasty. ${ }^{47}$ Ropivacaine is associated with a more rapid postoperative recovery of sensory and motor function. Whiteside et al found the same results by comparing $15 \mathrm{mg}$ hyperbaric ropivacaine $0.5 \%$ with $15 \mathrm{mg}$ hyperbaric bupivacaine 
$0.5 \%{ }^{48}$ When compared with $7.5 \mathrm{mg}$ of $0.5 \%$ hyperbaric levobupivacaine for outpatient knee arthroscopy, $7.5 \mathrm{mg}$ of $0.5 \%$ ropivacaine was also associated with shorter block time and faster home discharge. ${ }^{49}$

A dose-finding study conducted with Chinese patients found that anesthesia was successful in $70 \%$ of patients undergoing cesarean section with spinal ropivacaine $20 \mathrm{mg}$. The ED50 was 16.7 (95\% CI: 14.1-18.8) mg and the ED95 ("an effective dose [success] was defined as a dose that provided adequate sensory dermatomal anesthesia to pin prick to T7 or higher and required no epidural top-up for surgery to be completed") ${ }^{49}$ was 26.8 (95\% CI: 23.6-34.1) mg. ${ }^{50}$ Hyperbaric ropivacaine is associated with higher cephalic spread (median [range] maximum block height to pinprick, $\mathrm{T} 1$ [T4-C2] versus $\mathrm{T} 3$ [T11-C3]) and faster onset to T4 dermatome (mean [standard deviation, SD] of 7.7 [4.9] versus 16.4 [14.1] minutes) when compared with plain ropivacaine. ${ }^{51}$

\section{Peripheral nerve and ocular block}

Ropivacaine is the most frequently used anesthetic for peripheral nerve block in the People's Republic of China. However, clinical trials comparing ropivacaine with bupivacaine or levobupivacaine in different peripheral nerve blocks are limited in the People's Republic of China. In other countries, there are some randomized, double-blind, single-center and multicenter trials comparing ropivacaine with bupivacaine ${ }^{52-54}$ or levobupivacaine ${ }^{52,55-58}$ in axillary brachial plexus, ${ }^{52}$ interscalene brachial plexus, ${ }^{53,55}$ gluteal ${ }^{56}$ and popliteal ${ }^{58}$ sciatic nerve, ${ }^{54}$ and anterior tibial/peritoneal nerve blocks ${ }^{57}$ for upper and lower limb surgery. Ropivacaine was also compared with levobupivacaine, ${ }^{59}$ lidocaine,${ }^{60}$ and a mixture of bupivacaine and lidocaine ${ }^{61,62}$ in bulbar nerve block for eye surgery. A prospective double-blind study compared $0.5 \%$ ropivacaine and $0.5 \%$ levobupivacaine with 1:200,000 epinephrine for axillary brachial plexus block, and found that the duration of sensory analgesia was significantly longer with levobupivacaine than with ropivacaine, but return of motor activity was faster with ropivacaine. ${ }^{63}$ However, another prospective randomized double-blind study showed that $0.5 \%$ ropivacaine was associated with longer mean onset time (SD) for sensory block (13.5 [2.9] versus 11.1 [2.6]) and motor block (19.0 [2.7] versus 17.1 [2.6]) compared to $0.5 \%$ levobupivacaine for infraclavicular brachial plexus block, but there was no significant difference in terms of effectiveness of analgesia 6 hours postoperatively. ${ }^{64}$

When using continuous peripheral infusion of low concentration of ropivacaine for postoperative analgesia, ropiva- caine showed a similar quality of pain relief as provided by bupivacaine ${ }^{65}$ or levobupivacaine ${ }^{66}$ However, patients receiving ropivacaine consumed more local anesthetic than patients receiving levobupivacaine. Ropivacaine $0.3 \%$ is associated with a significant reduction of morphine consumption and better sleep quality for the first operative night compared with ropivacaine $0.2 \%$ for continuous interscalene analgesia. ${ }^{67}$

\section{Local infiltration and intra-articular administration}

Local anesthetics have become increasingly popular for management of postoperative pain for their good analgesic effects and simple, safe, and inexpensive properties ${ }^{68}$ The efficacy of local infiltration with ropivacaine for postoperative analgesia was investigated in a number of trials in Chinese patients undergoing laparoscopic cholecystectomy ${ }^{69}$ open hepatic surgery, ${ }^{70}$ gynecological hysteroscopy, and laparoscopy. ${ }^{71}$ Pre- or postoperative wound infiltration with ropivacaine was associated with short-term, dose-dependent relief of postoperative pain in patients. ${ }^{72}$ The analgesia effect provided by ropivacaine was similar to that achieved with bupivacaine in patients undergoing inguinal hernia repair, ${ }^{73}$ while it was much better than that achieved with levobupivacaine in patients undergoing minor breast surgery. ${ }^{74}$ Most of the studies about intra-articular administration of ropivacaine involved patients undergoing knee surgery. ${ }^{17,75}$ In a randomized, double-blind study, intra-articular $30 \mathrm{~mL}$ ropivacaine $0.75 \%$ provided better postoperative analgesia than bupivacaine and placebo. The visual analogue scale scores at rest and during mobilization were lower in patients who received ropivacaine. ${ }^{75}$

\section{Management of labor pain}

Lumbar epidural ropivacaine for pain relief during active labor is as established practice in Chinese patients. Across the epidural ropivacaine trials, there were no significant differences between ropivacaine and bupivacaine according to analgesia or motor block, ${ }^{7}$ although ropivacaine may be $25 \%$ less potent than bupivacaine in achieving analgesia in $50 \%$ of women. ${ }^{76}$ The volume and concentration were not significant factors influencing the efficacy of a single $30 \mathrm{mg}$ bolus of epidural ropivacaine for labor analgesia. ${ }^{77}$ In a large, randomized, double-blind trial, epidural infusion of $0.25 \%$ ropivacaine was associated with shorter duration of the first stage of labor compared with $0.25 \%$ bupivacaine; however, there was no difference in any other obstetric or neonatal outcome. ${ }^{78} \mathrm{~A}$ recent study supported the conclusion that a bolus of $15 \mathrm{~mL}$ of $0.0625 \%$ ropivacaine, bupivacaine, or levobupivacaine 
with fentanyl $2 \mu \mathrm{g} / \mathrm{mL}$ epidurally in nulliparous women confers adequate analgesia, with no significant influence on mode of delivery, duration of labor, or neonatal outcome. ${ }^{79}$ The addition of fentanyl to epidural ropivacaine was shown to significantly prolong the analgesia duration and increase patient satisfaction. ${ }^{80}$

\section{Dosage and administration}

In the People's Republic of China, ropivacaine is available in $0.2 \%, 0.5 \%, 0.75 \%$, and $1 \%$ solutions in $10 \mathrm{~mL}$ ampoules. It is indicated in adults for surgical anesthesia (epidural administration, intrathecal administration, peripheral nerve block, or cutaneous infiltration); for postoperative pain relief (epidural administration, peripheral nerve block, or wound instillation); and for labor analgesia (epidural administration). In children, it is indicated for epidural administration and peripheral nerve block for postoperative or acute pain management.

\section{Toxicity and tolerability}

Unlike other drugs, local anesthetics are administered in close proximity to their intended site of action. The systemic absorption occurs generally slowly, thus extremely rare systemic toxic reactions can occur. However, local anesthetics have the potential to induce central nervous system (CNS) and cardiovascular toxicity at high plasma concentration. ${ }^{7}$ As a pure left-isomer, ropivacaine has been shown to have less toxic effects on the CNS and the cardiovascular system. ${ }^{38}$

As data on toxicity of ropivacaine in humans are limited, many data are derived from in vitro studies or animal studies. One in vitro study suggested that half-maximal neurotoxic concentration of ropivacaine is lower than that of bupivacaine.$^{81}$ Intrathecally administered ropivacaine was also demonstrated in animal studies to be less neurotoxic than bupivacaine. ${ }^{82,83}$ Ropivacaine decreases the maximum rate of depolarization and prolongs QRS in isolated heart study ${ }^{84}$ A classic study conducted with volunteers found that the threshold for CNS toxicity was apparent at a mean free plasma concentration of approximately $0.6 \mathrm{mg} / \mathrm{L}$ for ropivacaine and $0.3 \mathrm{mg} / \mathrm{L}$ for bupivacaine. ${ }^{85}$ Another study demonstrated that the majority of cardiovascular and CNS symptoms occurred at plasma concentration of 1-2 $\mu \mathrm{g}$ / $\mathrm{mL}$ in healthy volunteers. ${ }^{86}$ Compared to bupivacaine, the cardiac toxicity, neurological injury after peripheral nerve block, and unwanted CNS effects may be less common for ropivacaine. ${ }^{12}$

Two comprehensive reviews have summarized ropivacaineassociated side effects. ${ }^{12,87}$ Ropivacaine produces similar side effects to those caused by bupivacaine and other local anesthetics for nerve block. ${ }^{12}$ The most common adverse event reported in adult patients following regional or local anesthesia using ropivacaine is hypotension $(30.1 \%-52.3 \%)$, followed by nausea $(11.3 \%-40.4 \%)$, fever $(1.1 \%-20.7 \%)$, and vomiting $(5.5 \%-20 \%) .{ }^{88}$ Epidural administration of ropivacaine for surgery generally produces dose-dependent adverse events similar to those observed with equal doses of bupivacaine. A randomized, open-label study found that doses of $0.75 \%$ plain ropivacaine at both $26.25 \mathrm{mg}$ and 33.75 $\mathrm{mg}$ have the same efficacy and safety in Chinese patients undergoing spinal anesthesia. ${ }^{89}$ The adverse effects during surgery were shivering (15\%), nausea (5\%), vomiting (5\%), hypotension (5\%), inadequate analgesia $(5 \%)$, and bradycardia $(5 \%)$ when $0.75 \%$ ropivacaine $26.25 \mathrm{mg}$ was administered intrathecally. ${ }^{89}$ The incidence of epidural ropivacaine-induced cardiovascular symptoms may be age-related: elderly patients were found to have a higher incidence of bradycardia and hypotension. ${ }^{90}$ However, the risk of systemic toxicity is independent of age. ${ }^{21}$

The quality of recovery after surgery is becoming a clinical issue of increasing significance, which is reflected in a change in focus from hospital-based to patient-based outcomes. A lot of clinical trials demonstrated that ropivacaine provided similar patient satisfaction compared to bupivacaine ${ }^{78,91,92}$ or levobupivacaine, ${ }^{57,93,94}$ regardless of the route of administration, although these trials were not primarily designed to investigate patient satisfaction. However, when compared to lidocaine, ropivacaine provided significantly higher rates of maternal satisfaction ( $84.3 \%$ versus $45.1 \%) .{ }^{95}$ Patients' overall satisfaction was $77 \%$ and $79 \%$ when ropivacaine was used for anesthesia or analgesia, respectively, with mean satisfaction scores of 9.6 out of 10 after 24 hours. ${ }^{59}$ A study conducted to investigate the postoperative quality of recovery in patients over the age of 65 years demonstrated that peripheral nerve block with ropivacaine was associated with better recovery in physiological, emotive (depression and anxiety), nociceptive (pain and nausea), and modified cognitive recovery than general anesthesia. ${ }^{96}$

\section{Conclusion}

Ropivacaine is a well-tolerated local anesthetic that is effective when administered as a peripheral nerve or ocular block, epidural or spinal block, or by topical application or local infiltration. In comparative trials, its clinical efficacy is not generally significantly different from that of bupivacaine or levobupivacaine, although it may have lower potency at lower doses. Ropivacaine has provided effective anesthesia for surgery and effective analgesia for postoperative and 
labor pain, and appears to be associated with less motor block, reduced CNS and cardiovascular toxicity, and higher satisfaction compared with bupivacaine. Ropivacaine is of particular importance in clinical use as regional anesthesia and the management of postoperative and obstetric pain.

\section{Disclosure}

The authors report no conflicts of interest in this work.

\section{References}

1. McClellan KJ, Faulds D. Ropivacaine: an update of its use in regional anaesthesia. Drugs. 2000;60:1065-1093.

2. Wong JO, Tan TD, Leung PO, Tseng KF, Cheu NW. Spinal anesthesia with two different dosages of $0.75 \%$ glucose-free ropivacaine: a comparison of efficacy and safety in Chinese parturients undergoing cesarean section. Acta Anaesthesiol Sin. 2003;41:131-138.

3. imshealth.com [homepage on the internet]. China Hospital Pharmaceutical Audit (IMSHealth). Available from: http://www.imshealth.com/ portal/site/imshealth. Accessed August 13, 2014.

4. Buckenmaier CC 3rd, Bleckner LL. Anaesthetic agents for advanced regional anaesthesia: a North American perspective. Drugs. 2005;65: $745-759$.

5. Schug SA, Saunders D, Kurowski I, Paech MJ. Neuraxial drug administration: a review of treatment options for anaesthesia and analgesia. CNS Drugs. 2006;20:917-933.

6. Kindler CH, Paul M, Zou H, et al. Amide local anesthetics potently inhibit the human tandem pore domain background $\mathrm{K}+$ channel TASK-2 (KCNK5). J Pharmacol Exp Ther. 2003;306:84-92.

7. Hansen TG. Ropivacaine: a pharmacological review. Expert Rev Neurother. 2004;4:781-791.

8. Rosenberg PH, Heinonen E. Differential sensitivity of A and C nerve fibres to long-acting amide local anaesthetics. Br J Anaesth. 1983;55:163-167.

9. Benhamou D, Ghosh C, Mercier FJ. A randomized sequential allocation study to determine the minimum effective analgesic concentration of levobupivacaine and ropivacaine in patients receiving epidural analgesia for labor. Anesthesiology. 2003;99:1383-1386.

10. Camorcia M, Capogna G, Columb MO. Minimum local analgesic doses of ropivacaine, levobupivacaine, and bupivacaine for intrathecal labor analgesia. Anesthesiology. 2005;102:646-650.

11. Lee YY, Ngan Kee WD, Fong SY, Liu JT, Gin T. The median effective dose of bupivacaine, levobupivacaine, and ropivacaine after intrathecal injection in lower limb surgery. Anesth Analg. 2009;109:1331-1334.

12. Simpson D, Curran MP, Oldfield V, Keating GM. Ropivacaine: a review of its use in regional anaesthesia and acute pain management. Drugs. 2005;65:2675-2717.

13. McGlade DP, Kalpokas MV, Mooney PH, et al. Comparison of $0.5 \%$ ropivacaine and $0.5 \%$ bupivacaine in lumbar epidural anaesthesia for lower limb orthopaedic surgery. Anaesth Intensive Care. 1997;25:262-266.

14. Lee BB, Ngan Kee WD, Plummer JL, Karmakar MK, Wong AS. The effect of the addition of epinephrine on early systemic absorption of epidural ropivacaine in humans. Anesth Analg. 2002;95:1402-1407.

15. Lee BB, Ngan Kee WD, Wong EL, Liu JY. Dose-response study of epidural ropivacaine for labor analgesia. Anesthesiology. 2001;94: 767-772.

16. Karmakar MK, Ho AM, Law BK, Wong AS, Shafer SL, Gin T. Arterial and venous pharmacokinetics of ropivacaine with and without epinephrine after thoracic paravertebral block. Anesthesiology. 2005;103: 704-711.

17. Chen S, Chen Z, Jin Y, et al. Pharmacokinetics and efficacy of ropivacaine in Chinese patients following intra-articular administration. Int J Clin Pharmacol Ther. 2013;51:393-400.

18. Karmakar MK, Aun CS, Wong EL, Wong AS, Chan SK, Yeung CK. Ropivacaine undergoes slower systemic absorption from the caudal epidural space in children than bupivacaine. Anesth Analg. 2002;94:259-265.
19. Kitayama M, Wada M, Hashimoto H, Kudo T, Yakoshi C, Hirota K. Plasma ropivacaine concentrations after ultrasound-guided transversus abdominis plane block for open retropubic prostatectomy. J Anesth. Epub December 18, 2013

20. Emanuelsson BM, Persson J, Alm C, Heller A, Gustafsson LL. Systemic absorption and block after epidural injection of ropivacaine in healthy volunteers. Anesthesiology. 1997;87:1309-1317.

21. Simon MJ, Veering BT, Vletter AA, Stienstra R, van Kleef JW, Burm AG. The effect of age on the systemic absorption and systemic disposition of ropivacaine after epidural administration. Anesth Analg. 2006;102: 276-282.

22. Burm AG, Stienstra R, Brouwer RP, Emanuelsson BM, van Kleef JW. Epidural infusion of ropivacaine for postoperative analgesia after major orthopedic surgery: pharmacokinetic evaluation. Anesthesiology. 2000;93:395-403.

23. Ekström G, Gunnarsson UB. Ropivacaine, a new amide-type local anesthetic agent, is metabolized by cytochromes P450 1A and $3 \mathrm{~A}$ in human liver microsomes. Drug Metab Dispos. 1996;24:955-961.

24. Tucker GT. Pharmacokinetics of local anaesthetics. Br J Anaesth. 1986;58:717-731.

25. Whiteside JB, Wildsmith JA. Developments in local anaesthetic drugs. Br J Anaesth. 2001;87:27-35.

26. Halldin MM, Bredberg E, Angelin B, et al. Metabolism and excretion of ropivacaine in humans. Drug Metab Dispos. 1996;24:962-968.

27. Li M, Cai HW, Ren F, Chen JH, Sun B. [Epidural anesthesia with ropivacaine by computerized infusion pump]. Zhong Nan Da Xue Xue Bao Yi Xue Ban. 2007;32:351-354. Chinese.

28. Liu J, Jiang Y, Pang D, Xi H, Liu Y, Li W. Associations between singlenucleotide polymorphisms and epidural ropivacaine consumption in patients undergoing breast cancer surgery. Genet Test Mol Biomarkers. 2013;17:489-493.

29. Wang G, Sun Y, Luo GJ, Lin PC, Liu PQ. [Effect of perioperative continuous epidural morphine administration on plasma D-dimer in patients undergoing total hip replacement]. Nan Fang Yi Ke Da Xue Xue Bao. 2006;26:523-525. Chinese.

30. Cai J, Guo QL, Zou WY. [Clinical anesthetic effects of epidural ropivacaine with tramadol]. Zhong Nan Da Xue Xue Bao Yi Xue Ban. 2004;29:218-220. Chinese.

31. Wan XH, Huang QQ, Su MX, Wan LJ, Huang HQ. [Security evaluation of bupivacaine, ropivacaine combined with fentanyl in postoperative continuous epidural analgesia]. Zhonghua Wai Ke Za Zhi. 2006;44:1200-1202. Chinese.

32. Crosby E, Sandler A, Finucane B, et al. Comparison of epidural anaesthesia with ropivacaine $0.5 \%$ and bupivacaine $0.5 \%$ for caesarean section. Can J Anaesth. 1998;45:1066-1071.

33. Bjornestad E, Smedvig JP, Bjerkreim T, Narverud G, Kollerøs D, Bergheim R. Epidural ropivacaine $7.5 \mathrm{mg} / \mathrm{mL}$ for elective Caesarean section: a double-blind comparison of efficacy and tolerability with bupivacaine 5 mg/mL. Acta Anaesthesiol Scand. 1999;43:603-608.

34. Kampe S, Tausch B, Paul M, et al. Epidural block with ropivacaine and bupivacaine for elective caesarean section: maternal cardiovascular parameters, comfort and neonatal well-being. Curr Med Res Opin. 2004;20:7-12.

35. Hillyard SG, Bate TE, Corcoran TB, Paech MJ, O’Sullivan G. Extending epidural analgesia for emergency Caesarean section: a meta-analysis. Br J Anaesth. 2011;107:668-678.

36. Pouzeratte Y, Delay JM, Brunat G, et al. Patient-controlled epidural analgesia after abdominal surgery: ropivacaine versus bupivacaine. Anesth Analg. 2001;93:1587-1592.

37. Casati A, Santorsola R, Aldegheri G, et al. Intraoperative epidural anesthesia and postoperative analgesia with levobupivacaine for major orthopedic surgery: a double-blind, randomized comparison of racemic bupivacaine and ropivacaine. J Clin Anesth. 2003;15:126-131.

38. Leone S, Di Cianni S, Casati A, Fanelli G. Pharmacology, toxicology, and clinical use of new long acting local anesthetics, ropivacaine and levobupivacaine. Acta Biomed. 2008;79:92-105.

39. Geng ZY, Wang DX, Wu XM. Minimum effective local anesthetic dose of intrathecal hyperbaric ropivacaine and bupivacaine for cesarean section. Chin Med J (Engl). 2011;124:509-513. 
40. Chen XZ, Chen H, Lou AF, Lü CC. Dose-response study of spinal hyperbaric ropivacaine for cesarean section. J Zhejiang Univ Sci B. 2006; 7:992-997.

41. Lee YY, Ngan Kee WD, Muchhal K, Chan CK. Randomized doubleblind comparison of ropivacaine-fentanyl and bupivacaine-fentanyl for spinal anaesthesia for urological surgery. Acta Anaesthesiol Scand. 2005;49:1477-1482.

42. Lee YY, Ngan Kee WD, Chang HK, So CL, Gin T. Spinal ropivacaine for lower limb surgery: a dose response study. Anesth Analg 2007;105:520-523.

43. Gautier PE, De Kock M, Van Steenberge A, et al. Intrathecal ropivacaine for ambulatory surgery. Anesthesiology. 1999;91:1239-1245.

44. McDonald SB, Liu SS, Kopacz DJ, Stephenson CA. Hyperbaric spinal ropivacaine: a comparison to bupivacaine in volunteers. Anesthesiology. 1999;90:971-977.

45. Malinovsky JM, Charles F, Kick O, et al. Intrathecal anesthesia: ropivacaine versus bupivacaine. Anesth Analg. 2000;91:1457-1460.

46. Camorcia M, Capogna G, Berritta C, Columb MO. The relative potencies for motor block after intrathecal ropivacaine, levobupivacaine, and bupivacaine. Anesth Analg. 2007;104:904-907.

47. McNamee DA, McClelland AM, Scott S, Milligan KR, Westman L, Gustafsson U. Spinal anaesthesia: comparison of plain ropivacaine $5 \mathrm{mg} \mathrm{mL}(-1)$ with bupivacaine $5 \mathrm{mg} \mathrm{mL}(-1)$ for major orthopaedic surgery. Br J Anaesth. 2002;89:702-706.

48. Whiteside JB, Burke D, Wildsmith JA. Comparison of ropivacaine $0.5 \%$ (in glucose $5 \%$ ) with bupivacaine $0.5 \%$ (in glucose $8 \%$ ) for spinal anaesthesia for elective surgery. Br J Anaesth. 2003;90:304-308.

49. Cappelleri G, Aldegheri G, Danelli G, et al. Spinal anesthesia with hyperbaric levobupivacaine and ropivacaine for outpatient knee arthroscopy: a prospective, randomized, double-blind study. Anesth Analg. 2005;101:77-82.

50. Khaw KS, Ngan Kee WD, Wong EL, Liu JY, Chung R. Spinal ropivacaine for cesarean section: a dose-finding study. Anesthesiology. 2001;95:1346-1350.

51. Khaw KS, Ngan Kee WD, Wong M, Ng F, Lee A. Spinal ropivacaine for cesarean delivery: a comparison of hyperbaric and plain solutions. Anesth Analg. 2002;94:680-685.

52. Liisanantti O, Luukkonen J, Rosenberg PH. High-dose bupivacaine, levobupivacaine and ropivacaine in axillary brachial plexus block. Acta Anaesthesiol Scand. 2004;48:601-606.

53. Altintas F, Gumus F, Kaya G, et al. Interscalene brachial plexus block with bupivacaine and ropivacaine in patients with chronic renal failure: diaphragmatic excursion and pulmonary function changes. Anesth Analg. 2005;100:1166-1171.

54. Beaulieu P, Babin D, Hemmerling T. The pharmacodynamics of ropivacaine and bupivacaine in combined sciatic and femoral nerve blocks for total knee arthroplasty. Anesth Analg. 2006;103:768-774.

55. Casati A, Borghi B, Fanelli G, et al. Interscalene brachial plexus anesthesia and analgesia for open shoulder surgery: a randomized, doubleblinded comparison between levobupivacaine and ropivacaine. Anesth Analg. 2003;96:253-259.

56. Casati A, Borghi B, Fanelli G, et al. A double-blinded, randomized comparison of either $0.5 \%$ levobupivacaine or $0.5 \%$ ropivacaine for sciatic nerve block. Anesth Analg. 2002;94:987-990.

57. Palmisani S, Arcioni R, Di Benedetto P, De Blasi RA, Mercieri M, Ronconi P. Ropivacaine and levobupivacaine for bilateral selective ankle block in patients undergoing hallux valgus repair. Acta Anaesthesiol Scand. 2008;52:841-844.

58. Casati A, Vinciguerra F, Cappelleri G, et al. Levobupivacaine $0.2 \%$ or $0.125 \%$ for continuous sciatic nerve block: a prospective, randomized, double-blind comparison with $0.2 \%$ ropivacaine. Anesth Analg. 2004;99:919-923.

59. Di Donato A, Fontana C, Lancia F, Celleno D. Efficacy and comparison of $0.5 \%$ levobupivacaine with $0.75 \%$ ropivacaine for peribulbar anaesthesia in cataract surgery. Eur J Anaesthesiol. 2006;23:487-490.

60. Olmez G, Cakmak SS, Caca I, Unlu MK. Intraocular pressure and quality of blockade in peribulbar anesthesia using ropivacaine or lidocaine with adrenaline: a double-blind randomized study. Tohoku J Exp Med. 2004;204:203-208.
61. Belyamani L, Kriet M, Laktaoui A, et al. [Peribulbar anesthesia: comparing $1 \%$ ropivacaine and a mixture of $0.5 \%$ bupivacaine 2\% lidocaine]. J Fr Ophtalmol. 2003;26:953-956. French.

62. Borazan M, Karalezli A, Oto S, Algan C, Aydin Akova Y. Comparison of a bupivacaine $0.5 \%$ and lidocaine $2 \%$ mixture with levobupivacaine $0.75 \%$ and ropivacaine $1 \%$ in peribulbar anaesthesia for cataract surgery with phacoemulsification. Acta Ophthalmol Scand. 2007;85: 844-847.

63. Cline E, Franz D, Polley RD, Maye J, Burkard J, Pellegrini J. Analgesia and effectiveness of levobupivacaine compared with ropivacaine in patients undergoing an axillary brachial plexus block. AANA J. 2004;72:339-345

64. Mageswaran R, Choy YC. Comparison of $0.5 \%$ ropivacaine and $0.5 \%$ levobupivacaine for infraclavicular brachial plexus block. Med $J$ Malaysia. 2010;65:300-303.

65. Borgeat A, Kalberer F, Jacob H, Ruetsch YA, Gerber C. Patient-controlled interscalene analgesia with ropivacaine $0.2 \%$ versus bupivacaine $0.15 \%$ after major open shoulder surgery: the effects on hand motor function. Anesth Analg. 2001;92:218-223.

66. Borghi B, Facchini F, Agnoletti V, et al. Pain relief and motor function during continuous interscalene analgesia after open shoulder surgery: a prospective, randomized, double-blind comparison between levobupivacaine $0.25 \%$, and ropivacaine $0.25 \%$ or $0.4 \%$. Eur J Anaesthesiol. 2006;23:1005-1009.

67. Borgeat A, Aguirre J, Marquardt M, Mrdjen J, Blumenthal S. Continuous interscalene analgesia with ropivacaine $0.2 \%$ versus ropivacaine $0.3 \%$ after open rotator cuff repair: the effects on postoperative analgesia and motor function. Anesth Analg. 2010;111:1543-1547.

68. Liu SS, Richman JM, Thirlby RC, Wu CL. Efficacy of continuous wound catheters delivering local anesthetic for postoperative analgesia: a quantitative and qualitative systematic review of randomized controlled trials. J Am Coll Surg. 2006;203:914-932.

69. Liu YY, Yeh CN, Lee HL, et al. Local anesthesia with ropivacaine for patients undergoing laparoscopic cholecystectomy. World $J$ Gastroenterol. 2009;15:2376-2380.

70. Chan SK, Lai PB, Li PT, et al. The analgesic efficacy of continuous wound instillation with ropivacaine after open hepatic surgery. Anaesthesia. 2010;65:1180-1186.

71. Liu HL, Ma CH, Zhang XQ, Yang Y, Song XL, Guo XY. [Combined efficacy of parecoxib and incisional ropivacaine infiltration on pain management after diagnostic hysteroscopy and laparoscopy]. Beijing Da Xиe Xие Bao. 2013;45:901-905. Chinese.

72. Mulroy MF, Burgess FW, Emanuelsson BM. Ropivacaine $0.25 \%$ and $0.5 \%$, but not $0.125 \%$, provide effective wound infiltration analgesia after outpatient hernia repair, but with sustained plasma drug levels. Reg Anesth Pain Med. 1999;24(2):136-141.

73. Pettersson N, Berggren P, Larsson M, Westman B, Hahn RG. Pain relief by wound infiltration with bupivacaine or high-dose ropivacaine after inguinal hernia repair. Reg Anesth Pain Med. 1999;24: 569-575.

74. Manfè AZ, Marchesini M, Bortolato A, Feltracco P, Lumachi F. Ropivacaine versus levobupivacaine for minor breast surgery in outpatients: inversion of postoperative pain relief efficacy. In Vivo. 2012;26:1075-1077.

75. Marret E, Gentili M, Bonnet MP, Bonnet F. Intra-articular ropivacaine $0.75 \%$ and bupivacaine $0.50 \%$ for analgesia after arthroscopic knee surgery: a randomized prospective study. Arthroscopy. 2005;21: 313-316.

76. Ngan Kee WD, Ng FF, Khaw KS, Lee A, Gin T. Determination and comparison of graded dose-response curves for epidural bupivacaine and ropivacaine for analgesia in laboring nulliparous women. Anesthesiology. 2010;113:445-453.

77. Chan L, Lee BB, Ngan Kee WD. A randomised double-blinded controlled trial of the effect of diluent volume on the efficacy of a single dose of epidural ropivacaine for labour analgesia. Int J Obstet Anesth 2006;15:201-205.

78. Lee BB, Ngan Kee WD, Ng FF, Lau TK, Wong EL. Epidural infusions of ropivacaine and bupivacaine for labor analgesia: a randomized, doubleblind study of obstetric outcome. Anesth Analg. 2004;98:1145-1152. 
79. Beilin Y, Guinn NR, Bernstein HH, Zahn J, Hossain S, Bodian CA. Local anesthetics and mode of delivery: bupivacaine versus ropivacaine versus levobupivacaine. Anesth Analg. 2007;105:756-763.

80. Bang EC, Lee HS, Kang YI, Cho KS, Kim SY, Park H. Onset of labor epidural analgesia with ropivacaine and a varying dose of fentanyl: a randomized controlled trial. Int J Obstet Anesth. 2012;21:45-50.

81. Werdehausen R, Fazeli S, Braun S, et al. Apoptosis induction by different local anaesthetics in a neuroblastoma cell line. Br J Anaesth. 2009;103:711-718.

82. Yamashita A, Matsumoto M, Matsumoto S, Itoh M, Kawai K, Sakabe T. A comparison of the neurotoxic effects on the spinal cord of tetracaine, lidocaine, bupivacaine, and ropivacaine administered intrathecally in rabbits. Anesth Analg. 2003;97:512-519.

83. Takenami T, Wang G, Nara Y, et al. Intrathecally administered ropivacaine is less neurotoxic than procaine, bupivacaine, and levobupivacaine in a rat spinal model. Can J Anaesth. 2012;59:456-465.

84. Arlock P. Actions of three local anaesthetics: lidocaine, bupivacaine and ropivacaine on guinea pig papillary muscle sodium channels (Vmax). Pharmacol Toxicol. 1988;63:96-104.

85. Knudsen K, Beckman Suurküla M, Blomberg S, Sjövall J, Edvardsson N. Central nervous and cardiovascular effects of iv infusions of ropivacaine, bupivacaine and placebo in volunteers. Br J Anaesth. 1997;78: 507-514.

86. Scott DB, Lee A, Fagan D, Bowler GM, Bloomfield P, Lundh R. Acute toxicity of ropivacaine compared with that of bupivacaine. Anesth Analg. 1989;69:563-569.

87. Markham A, Faulds D. Ropivacaine. A review of its pharmacology and therapeutic use in regional anaesthesia. Drugs. 1996;52:429-449.

88. Naropin ${ }^{\circledR}$ (ropivacaine $\mathrm{HCl}$ ) injection; prescribing information (Canada). AstraZeneca. Available from: http://www.astrazeneca. $\mathrm{ca} / \mathrm{cs} /$ BlobServer?blobcol=pdffile \&blobheader=application $\% 2 \mathrm{~F}$ pdf\&blobheadername $1=$ Content-Disposition\&blobheadername2=MDT-T ype \&blobheadervalue $1=$ inline $\% 3 \mathrm{~B}+$ filename $\% 3$ DProduct-Monograph. pdf\&blobheadervalue $2=$ abinary $\% 3 \mathrm{~B}+$ charset $\% 3 \mathrm{DUTF}-8 \&$ blobkey $=\mathrm{id} \&$ blobnocache $=$ true $\&$ blobtable $=$ AZ_FixedURLPDF \&blobwhere $=128558$ 5474170\&ssbinary=true. Accessed August 28, 2014.
89. Wong JO, Tan TD, Leung PO, Tseng KF, Cheu NW, Tang CS. Comparison of the effect of two different doses of $0.75 \%$ glucose-free ropivacaine for spinal anesthesia for lower limb and lower abdominal surgery. Kaohsiung J Med Sci. 2004;20:423-430.

90. Simon MJ, Veering BT, Stienstra R, van Kleef JW, Burm AG. The effects of age on neural blockade and hemodynamic changes after epidural anesthesia with ropivacaine. Anesth Analg. 2002;94:1325-1330.

91. Dresner M, Freeman J, Calow C, Quinn A, Bamber J. Ropivacaine 0.2\% versus bupivacaine $0.1 \%$ with fentanyl: a double blind comparison for analgesia during labour. Br J Anaesth. 2000;85:826-829.

92. Fernández-Guisasola J, Serrano ML, Cobo B, et al. A comparison of $0.0625 \%$ bupivacaine with fentanyl and $0.1 \%$ ropivacaine with fentanyl for continuous epidural labor analgesia. Anesth Analg. 2001;92: 1261-1265.

93. Messina M, Magrin S, Bignami E, et al. Prospective randomized, blind comparison of ropivacaine and levobupivacaine for superficial plexus anesthesia in carotid endoarterectomy. Minerva Anestesiol. 2009;75:7-12.

94. Purdie NL, McGrady EM. Comparison of patient-controlled epidural bolus administration of $0.1 \%$ ropivacaine and $0.1 \%$ levobupivacaine, both with $0.0002 \%$ fentanyl, for analgesia during labour. Anaesthesia. 2004;59:133-137.

95. Gutton C, Bellefleur JP, Puppo S, et al. Lidocaine versus ropivacaine for perineal infiltration post-episiotomy. Int $J$ Gynaecol Obstet. 2013;122:33-36.

96. Liu J, Yuan W, Wang X, et al. Peripheral nerve blocks versus general anesthesia for total knee replacement in elderly patients on the postoperative quality of recovery. Clin Interv Aging. 2014;9: 341-350.
Drug Design, Development and Therapy

\section{Publish your work in this journal}

Drug Design, Development and Therapy is an international, peerreviewed open-access journal that spans the spectrum of drug design and development through to clinical applications. Clinical outcomes, patient safety, and programs for the development and effective, safe, and sustained use of medicines are a feature of the journal, which

\section{Dovepress}

has also been accepted for indexing on PubMed Central. The manuscript management system is completely online and includes a very quick and fair peer-review system, which is all easy to use. Visit $\mathrm{http}: / / \mathrm{www}$.dovepress.com/testimonials.php to read real quotes from published authors. 